\title{
A study on the effects of different factors influencing on customer loyalty, profitability and word of mouth advertisement for gaining competitive advantage in tourism industry
}

\author{
Naser Azad*, Maryam Safaei and Mahdieh Shahrabi Farahani
}

Department of Management and Accounting, South Tehran Banch, Islamic Azad University, Tehran, Iran

\begin{tabular}{l} 
Department of Management and Accoun $\mathbf{~ O ~ N ~ I ~ C ~ L ~ E ~}$ \\
\hline Article history: \\
Received December 2, 2013 \\
Accepted 8 May 2014 \\
Available online \\
May 152014 \\
\hline Keywords: \\
Customer loyalty \\
Tourism industry \\
Word of mouth \\
Competitive advantage
\end{tabular}
\begin{abstract}
A B S T R A C T
This paper presents an empirical investigation to study the effects of various factors influencing on customer loyalty, profitability and word of mouth advertisement for gaining competitive advantage in tourism industry. The study designs a questionnaire in Likert scale and distributes it among a random sample of 500 people who purchased some tours from travel agencies. Using structural equation modeling, the study has determined a positive and meaningful impact of pricing strategy, amenity, tourism services, content of trip, marketing mix elements, brand equity, competitive advantage and being exclusive on gaining competitive advantage. In addition, being exclusive and value creation influence positively on word of mouth advertisement. Finally, value creation influences on profitability, positively.
\end{abstract}

C) 2014 Growing Science Ltd. All rights reserved.

\section{Introduction}

During the past few years, there have been various factors influencing tourism industry in the world such as customer loyalty, word of mouth advertisement, etc. (Ma, 1999, 2002; Timms, 2006; Bandyopadhyay \& Martell, 2007; Grønhaug \& Ottesen, 2007; Halim, 2011). According to Burmann et al. (2009), in the context of increasingly interchangeable product and service offerings, brands are important drivers for product purchasing and consumer decisions even in tourism industry. Bendixen et al. (2004) described the concept of brand equity in a specific industrial marketing setting. They also investigated the sources of brand equity as well as the suitable communications strategy and the relative importance of brand relative to other purchase criteria. They reported that while brand equity had essential role on marketing and price and delivery were more important. Bennett and Smith (2002) applied a survey of SMEs in the UK to evaluate the factors associated with their competitive conditions and their competitive advantage and confirmed that, as SME businesses grow, they tend to develop their strategy to look for specialization and differentiation of their products and services and diversification of their customer base.

\footnotetext{
*Corresponding author.

E-mail addresses: N azad@azad.ac.ir (N. Azad) 
Chailan (2008) tried to understand more about brand portfolio management by describing the brand portfolio strategies of four leading cosmetics firms. They concentrated on two questions including the reasons lead firms to develop, or not, a brand portfolio strategy, and how brand portfolio management may generate a higher and stronger level of competitive advantage, which is harder to achieve. They explained that an aggregation of brands was not in and of itself a brand portfolio. Dacko (2012) synthesized, organized, and explained multidisciplinary study influential to a service firm's application of a cyclical time-based marketing method, which could be aptly termed time-of-day services marketing, to express a general process and framework to help in the evaluation of its strategic use. They reported that the principal advantages to service companies of adopting a time-ofday services method in varying degrees were that it was able to help the firm in offering multiple, unique value-propositions, providing superior contextual value to the customer, enhancing customer perceptions of value in relation to their requirements.

Eraqi (2006) made an assessment on the customer's views associated with tourism quality in Egypt and tried to measure the extent to which tourism business environment was creative and innovative as necessary conditions for internal customer satisfaction. They reported that quality could be considered as a philosophy for helping tourism organization/destination when taking decisions associated with tourism services; tourism business environment in Egypt did not support the internal customer satisfaction due to the lack of an appropriate system for helping people be creative and innovative. Grandy and Wicks (2008) explored how small companies in the tattooing industry could shape institutional expectations of value for consumers in a changing industry. The results disclosed efforts of companies to build and to increase organizational legitimacy through the prominence of discourses of professionalism. Halim (2011) attempted to detect new potential objects of coastal tourism, which could be implemented as parameter of the competitive advantage coastal tourism business, which would match with the implementation of ecotourism's concept. Kuikka and Laukkanen (2012) explored the antecedents of brand loyalty in the chocolate market and reported that brand satisfaction was the most important factor for brand loyalty within the chocolate market, followed by brand value and brand equity. Kim and Hyun (2011) presented a model to study the effect of marketing-mix efforts and corporate image on brand equity in the IT software sector. Kim et al. (2011), in another study, investigated the impacts of customers' perceptions of brand personality in casual theme restaurants. Netemeyer et al. (2004) developed and validated various measures of facets of customer-based brand equity.

\section{The proposed study}

This paper presents an empirical investigation to study the effects of various factors influencing on customer loyalty, profitability and word of mouth advertisement for gaining competitive advantage in tourism industry. Fig. 1 demonstrates the structure of the proposed model.

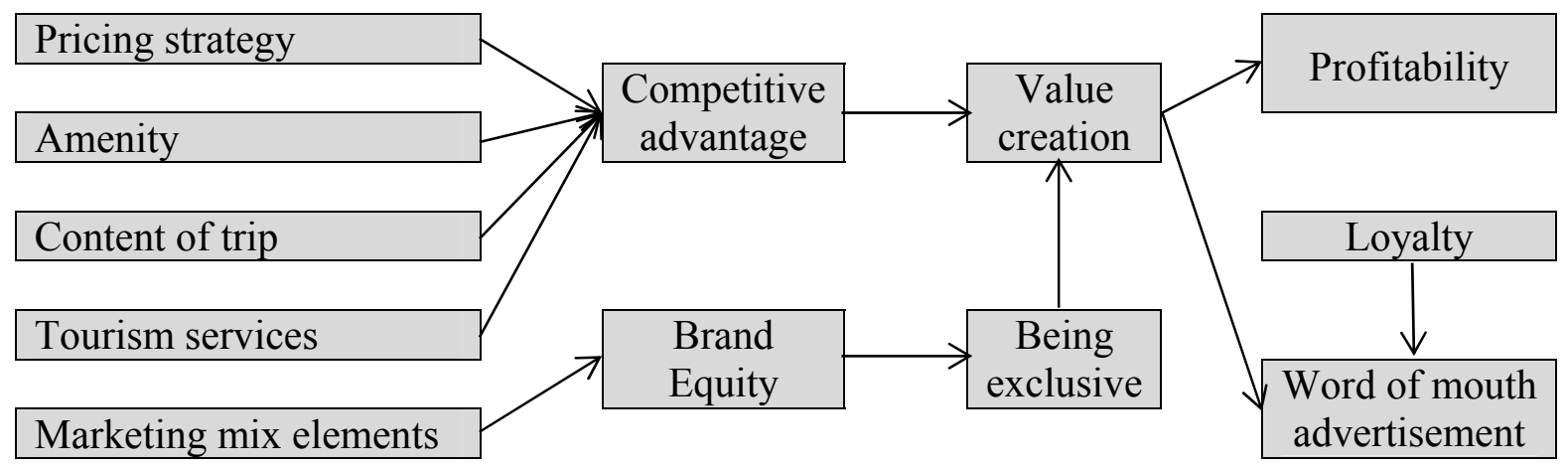

Fig. 1. The proposed study 
The study designs a questionnaire in Likert scale and distributes it among a random sample of 500 people who purchased some tours from travel agencies. The study uses structural equation modeling to verify the effects of various factors.

\section{The results}

The paper uses structural equation modeling to verify the effects various factors on development of tourism industry. Fig. 2 shows the results of the implementation of our survey.

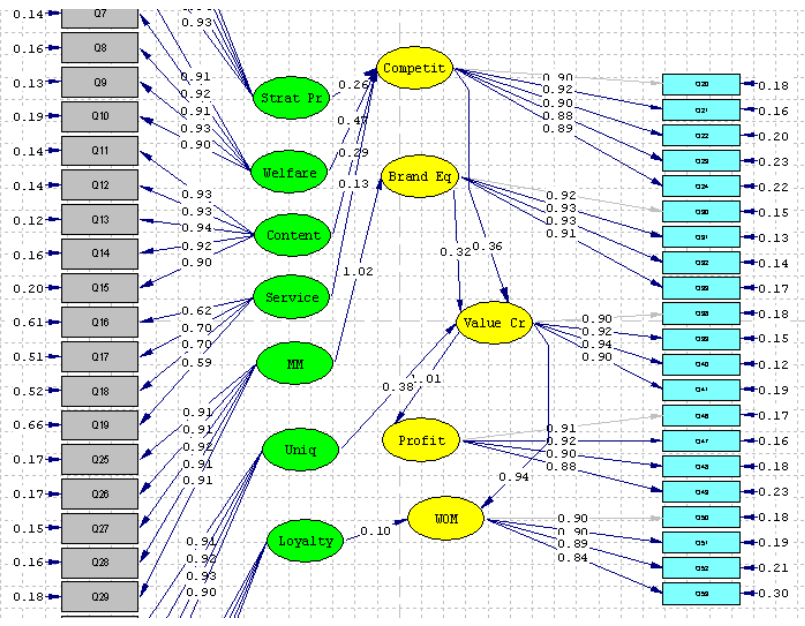

The results of standard coefficients

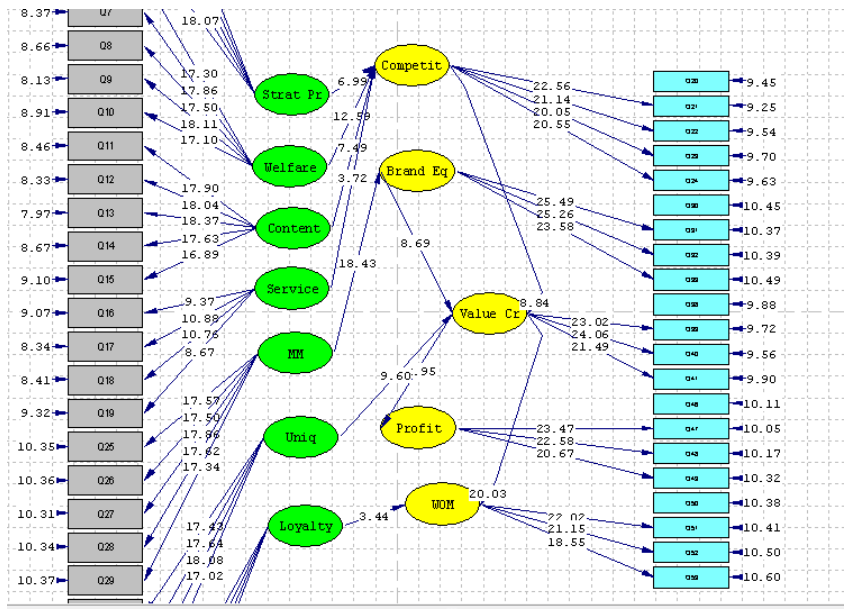

The results of $t$-student values

Fig. 2. The results of structural equation modeling

The results of some statistical observations are Goodness of Fit Index (GFI) $=0.96$, Adjusted Goodness of Fit Index $(\mathrm{AGFI})=0.91, \mathrm{NFI}=0.94$ and NNFI $=0.95$ with Root Mean Square Error of Approximation $($ RMSEA $)=0.036$ and they are within desirable limits.

\section{Discussion and conclusion}

Based on the results of structural equation modeling, we can confirm the effects of various variables. Table 1 demonstrates the results of the survey.

\section{Table 1}

The results of testing the effects of various factors

\begin{tabular}{lccc}
\hline Relationship & $\beta$ & t-value & Result \\
\hline Pricing strategy $\rightarrow$ Competitive advantage & 0.26 & 6.99 & Confirmed \\
Amenity $\rightarrow$ Competitive advantage & 0.47 & 12.59 & Confirmed \\
Tourism services $\rightarrow$ Competitive advantage & 0.13 & 3.72 & Confirmed \\
Content trip $\rightarrow$ Competitive advantage & 0.29 & 7.49 & Confirmed \\
Marketing mix elements $\rightarrow$ Competitive advantage & 1.02 & 10.43 & Confirmed \\
Brand equity $\rightarrow$ Value creation & 0.32 & 8.69 & Confirmed \\
Competitive advantage $\rightarrow$ Value creation & 0.36 & 8.84 & Confirmed \\
Being exclusive $\rightarrow$ Value creation & 0.38 & 9.60 & Confirmed \\
Loyalty $\rightarrow$ Word of mouth & 0.10 & 3.44 & Confirmed \\
Value creation $\rightarrow$ Profitability & 1.01 & 22.95 & Confirmed \\
Value creation $\rightarrow$ Word of mouth & 0.94 & 20.03 & Confirmed \\
\hline
\end{tabular}

As we can observe from the results of Table 1, pricing strategy, amenity, tourism services, content trip and marketing mix elements influence on competitive advantage, positively. In addition, brand 
equity, competitive advantage and being exclusive influence on value creation, positively. Finally, customer loyalty and value creation create more word of mouth and value creation influences on word of mouth, positively.

\section{Acknowledgement}

The authors would like to thank the anonymous referees for constructive comments on earlier version of this paper.

\section{References}

Bandyopadhyay, S., \& Martell, M. (2007). Does attitudinal loyalty influence behavioral loyalty? A theoretical and empirical study. Journal of Retailing and Consumer Services, 14(1), 35-44.

Bendixen, M., Bukasa, K. A., \& Abratt, R. (2004). Brand equity in the business-to-business market. Industrial Marketing Management, 33(5), 371-380.

Bennett, R. J., \& Smith, C. (2002). Competitive conditions, competitive advantage and the location of SMEs. Journal of small business and enterprise development, 9(1), 73-86.

Burmann, C., Jost-Benz, M., \& Riley, N. (2009). Towards an identity-based brand equity model. Journal of Business Research, 62(3), 390-397.

Chailan, C. (2008). Brands portfolios and competitive advantage: an empirical study. Journal of Product \& Brand Management, 17(4), 254-264.

Dacko, S. G. (2012). Time-of-day services marketing. Journal of Services Marketing, 26(5), 375-388.

Eraqi, M. I. (2006). Tourism services quality (TourServQual) in Egypt: the viewpoints of external and internal customers. Benchmarking: An International Journal, 13(4), 469-492.

Grandy, G., \& Wicks, D. (2008). Competitive advantage as a legitimacy-creating process. Qualitative Research in Organizations and Management: An International Journal, 3(1), 21-41.

Grønhaug, K., \& Ottesen, G. G. (2007). Can theoretical knowledge and application yield competitive advantage?. Marketing Intelligence \& Planning,25(3), 232-240.

Halim, H. S. (2011). Improving coastal tourism business competitiveness: Using ecotourism's concept to explore to potential of coastal tourism business Pandeglang and Serang Districts. Banten. West-Java. Indonesia. International Journal of Business and Social Science, 2(11), 87-90.

Kim, J. H., \& Hyun, Y. J. (2011). A model to investigate the influence of marketing-mix efforts and corporate image on brand equity in the IT software sector. Industrial Marketing Management, 40(3), 424-438.

Kim, D., Magnini, V. P., \& Singal, M. (2011). The effects of customers' perceptions of brand personality in casual theme restaurants. International Journal of Hospitality Management, 30(2), 448-458.

Kuikka, A., \& Laukkanen, T. (2012). Brand loyalty and the role of hedonic value. Journal of Product \& Brand Management, 21(7), 529-537.

Ma, H. (1999). Creation and preemption for competitive advantage. Management Decision, 37(3), $259-267$.

Ma, H. (2002). Competitive advantage: what's luck got to do with it?. Management Decision, 40(6), $525-536$

Netemeyer, R. G., Krishnan, B., Pullig, C., Wang, G., Yagci, M., Dean, D., ... \& Wirth, F. (2004). Developing and validating measures of facets of customer-based brand equity. Journal of Business Research, 57(2), 209-224.

Timms, B. (2006). Caribbean agriculture-tourism linkages in a neoliberal world: Problems and prospects for St Lucia. International Development Planning Review, 28(1), 35-56. 